\title{
Museum dan Galeri \\ (Tantangan dan Solusi)
}

\author{
Sasferi Yendra \\ Fakultas Bahasa dan Seni, Universitas Negeri Padang \\ ferirupa@gmail.com
}

\begin{abstract}
Abstrak
Latar belakang penelitian ini adalah fenomena masyarakat luas yang terlihat kesadaran untuk berkunjung ke museum, terlihat pada akun sosial media masyarakat zaman sekarang yang semakin marak. Ruang pamer museum merupakan sebuah wadah aktivitas yang dilakukan pengguna dalam museum yang berfungsi sebagai elemen utama visualisasi, ruang sebagai program, dan ruang sebagai susunan tata letak. Sering ditemukannya ruang pamer yang tidak sesuai harapan dan lemahnya interaksi museum terhadap pengunjung, kegagalan kepuasan pengunjung terhadap ruang pamer dapat menjadi kendala menurunnya minat untuk datang kembali.
\end{abstract}

Kata kunci: ruang pertunjukan, museum, interior, kontemporer

\begin{abstract}
The background of this study is a phenomenon of the wider community that shows awareness to visit the museum, seen in the social media accounts of today's society which are increasingly prevalent. The museum exhibition room is a place of activity carried out by users in the museum which functions as the main element of visualization, space as a program, and space as an arrangement of layout. Often found showrooms that do not match expectations and weak museum interaction with visitors, the failure of visitor satisfaction to the showroom can be an obstacle to the decline in interest in coming back.
\end{abstract}

Keywords: showroom, museum, interior, contemporary

\section{PENDAHULUAN}

Seni rupa di Indonesia merupakan salah satu bentuk ekspresi yang dihadirkan dari berbagai tradisi dan budaya Indonesia melalui ilmu seni rupa. Indonesia terus berkembang sejalan dengan kreativitas dan kesadaran akan pentingnya sebuah pergerakan seni rupa dalam berkehidupan. Hal tersebut berdampak pada hasil karya seni rupa yang menjadi lebih modern. Dalam bidang seni, khususnya seni rupa, pengertian modern bisa juga diartikan sebagai suatu seni yang baru, yang didasari pola penciptaan yang baru dengan sikap dan watak para seniman yang kreatif. Seiring perkembangan zaman modern ini, masyarakat telah disuguhi dengan segala kemudahan teknologi yang sangat modern dan kompleks. Namun, dalam segala kelebihan teknologi tersebut tetap membawa manusia untuk terus berinteraksi secara fisik dan eksistensi masa benda, jadi tidak hanya terpaku pada teknologi. Di bidang seni dan desain, salah satu contoh adalah museum, yang dewasa ini sudah terlihat lebih dilirik eksistensinya oleh kalangan masyarakat, baik menengah maupun menengah ke atas. 
Pada saat ini, banyak museum yang sudah terlihat modern dan sarat akan teknologi mutakhir, namun ada pula museum yang masih mengandalkan sistem operasional sumber daya manusia. Perkembangan museum dan galeri juga menimbulkan apresiasi dari masyarakat kota besar dan kecil, mengejar kelas elit yang sulit dipahami, yang memiliki uang dan ingin "budaya" sebagai bagian dari gaya hidupnya. Berdasarkan Richard Florida's (2002), “The Rise of Kelas Kreatif” menjual estetika perkotaan dan model ekonomi ke kota-kota yang berjuang untuk membangun kembali diri mereka sendiri untuk melayani "kelas" baru ini. Demi melayani hasrat akan berkesenian dan apresiasi para penikmat seni semakin meningkat maka, bermunculanlah pembangunan yang begitu pesat hingga setiap provinsi memiliki museum dan galeri.

Menurut A. C. Parker seorang ahli permuseuman Amerika, "Sebuah Museum dalam pengertian modern adalah sebuah lembaga yang secara aktif melakukan tugas menjelaskan dunia, manusia, dan alam". Sedangkan definisi dari konservasi adalah, merupakan usaha pemeliharaan, perawatan, perbaikan, pencegahan, dan penjagaan benda-benda koleksi dari penyebab kerusakan. Benda yang dipamerkan di museum merupakan suatu media untuk menginformasikan masa lampau kepada kita, terutama generasi muda sekarang yang tidak bersamaan hidup dengan generasi tua pada masa lampau (Rumansara, 2013).

Museum sendiri memiliki tujuan pelestarian yakni agar masyarakat tidak melupakan atau tidak mengenal lagi kekayaan budaya mereka sendiri. Salah satu upaya yang harus dilakukan adalah memberikan pembelajaran tentang museum kepada generasi muda. Sebelum kemerdekaan, museum didirikan untuk kepentingan pelestarian kebudayaan, memperkenalkan kebudayaan kepada rakyat. Sementara pendirian museum setelah kemerdekaan adalah untuk kepentingan pelestarian dan pengembangan warisan budaya juga sebagai sarana pendidikan nonformal. Selain tujuan pelestarian di atas, museum juga sebagai sarana informasi kepada masyarakat seperti yang disebutkan oleh Rumansara, bahwa generasi muda sekarang dapat menggali informasi mengenai koleksi benda-benda zaman dahulu.

Museum adalah industri berkembang yang telah terlibat dalam debat yang gencar tentang apa yang membentuk sebuah museum, tentang aturan-aturan yang dengannya museum diharapkan untuk meningkatkan pengetahuan mengenai histori atau peninggalan-peninggalan yang ada pada sebuah daerah, termasuk pertanyaan tentang akreditasi, tentang estetika, dan terutama tentang uang dan sumber daya.

Permasalahan yang dialami oleh museum milik negara pada umumnya yaitu bersikap pasif dengan mengandalkan anggaran pemerintah yang terbatas, pada kewajiban terhadap perawatan dan penyimpanan koleksi. Permasalahan pada pengelolaan museum swasta berbeda; dana tidak mengandalkan anggaran pemerintah, dan museum yang dikelola secara swasta biasanya memiliki komunitas untuk penganggaran untuk keperluan museum. Selain perawatan koleksi museum, yang perlu dipertimbangkan dalam sebuah kesuksesan museum adalah pertimbangan sirkulasi pengunjung yang baik, sistem informasi yang jelas mengenai benda yang dipajang, koordinasi setiap objek yang ditampilkan dengan ruang lingkup pamer cukup informatif atau tidak, bagi pengunjung yang menikmati karya. 
Kata kuncinya adalah untuk apa dan mengapa museum sangat dibutuhkan dalam era modern yang semua bisa dilakukan dengan teknologi yang tiap hari bahkan jam meningkat secara cepat. Penempatannya mencerminkan pertanyaan kunci yang terus berlanjut ke direktur museum: siapa dan untuk apa ini?

Perdana Menteri Robert Peel berpendapat bahwa salah satu "tujuan" Galeri Nasional maupun museum adalah untuk "memperkuat ikatan persatuan antara negara yang lebih kaya dan lebih miskin". Hasilnya cukup luar biasa dan layak dikutip panjang lebar dari esai MacGregor yang bergerak dan elegan: "Pada 1856, Jackson the Builders memiliki 338 orang yang telah melakukan 583 kunjungan ke Galeri Nasional".

Masalah yang sering terjadi di pengelolaan museum saat ini, bagaimana kebutuhan museum demi meningkatkan mutu dan tercapainya sebuah tujuan pihak-pihak yang tidak bertanggung jawab seperti masalah yang terjadi seperti kasus Museum Seni Detroit baru-baru ini yang harus menghadapi dalil bahwa ia mungkin harus menjual potongan koleksi yang terkenal di dunia sebagai Kota Detroit, berjuang untuk muncul dari kebangkrutan. Maka, untuk memberikan gambaran beberapa latar belakang sejarah, para profesional museum dan tentunya dewan, mereka sadar akan segudang tantangan, menantang munculnya museum-museum. Semua lembaga budaya, besar maupun kecil, tetapi secara umum publik tetap tidak tahu tentang mereka kecuali ketika seseorang diancam akan ditutup atau ada krisis besar yang membuat keberadaan mereka dipertanyakan.

Peran Museum Barli dalam dunia seni rupa bukan hanya sebagai ruang pamer atas karya-karya dari tokoh seniman Barli Sasmitawinata saja, melainkan sebuah sarana edukatif mengenai budaya yang terlukis dari karya-kaya beliau, seperti yang diungkapkan oleh Nakisbandiah dalam bukunya yang berjudul "Kehidupanku Bersama Barli", adalah sebagai berikut: "Kepentingan itu tidak hanya terletak pada fungsi Museum Barli sebagai tempat penyebaran nilai-nilai budaya yang mengaitkan masa lalu dengan masa kini, tetapi juga berfungsi sebagai studi sekaligus aset wisata" (Nakisbandiah, 2004, hlm. 87).

Pada masa kini, museum tidak lagi hanya sebagai tempat untuk memamerkan karya seni, namun museum pun telah memperbolehkan ruang publik di dalamnya dipergunakan untuk acara kegiatan kemasyarakatan, seperti acara seminar, bedah buku, demi mengasah intelektual dan kepekaan masyarakat terhadap eksistensi museum serta yang terpenting adalah museum tidak terkesan eksklusif hanya untuk kalangan orang tertentu saja atau untuk sebagian kecil masyarakat (Khoirnafiya, 2012). Tidak jarang terlihat bahwa museum dijadikan tempat untuk berlangsungnya beberapa acara, seperti bedah buku, peluncuran buku, dan lain sebagainya. Hal ini menambah daya tarik museum dan masyarakat pun akan lebih terdorong untuk berkunjung ke museum.

Pengelolaan museum dan galeri dalam penyusunan koleksi seni, baik berupa lukisan, artwork, instalasi, dan lainnya, sangat penting dalam sebuah ruang pamer. Kendala atau masalah yang harus diperhatikan dan sering dijumpai di area pamer museum adalah: sirkulasi ruang pamer yang memadai dan mendukung kegiatan pengunjung dalam menikmati karya seni, bagaimana sebuah ruang pamer dalam museum tersebut memberikan kepuasan dan menarik untuk dikunjungi kembali oleh masyarakat dan khalayak ramai, baik pecinta seni maupun yang hanya sekedar berkunjung. 


\section{METODE}

Metode penelitian yang akan digunakan adalah metode kualitatif dengan melakukan studi pustaka, studi lapangan, dan interview. Studi pustaka dilakukan untuk mengetahui informasi yang berkaitan dengan ruang pamer dan perkembangan museum dan galeri. Sedangkan studi lapangan akan dilakukan untuk mengobservasi bagian interior ruang pamer tersebut. Studi pustaka yang dilakukan adalah mencari data yang relevan dengan topik penelitian, yaitu mengenai kriteria ruang pamer dan pengelolaan museum demi tercapainya tujuan dan visi museum, dan juga mengedukasi masyarakat.

Objek penelitian yang diambil adalah sebuah museum seni kontemporer. Survei pada objek penelitian dilakukan guna mengobservasi keberadaan ruang pamer di dalam museum tersebut terkait dengan system display, pencahayaan, dan sirkulasi yang baik. Analisis terhadap beberapa aspek interior mengenai kelebihan dan kekurangan yang terdapat pada ruang pamer. Metode penelitian yang akan digunakan adalah metode kualitatif dan kuantitatif, dengan metode pengumpulan data, juga dilakukan dengan dua tahap. Tahap pertama adalah pengumpulan data sekunder melalui berbagai sumber pustaka seperti buku, artikel jurnal, sumber online, koran, serta laporan penelitian yang berkaitan dengan topik penelitian yakni mengenai museum, tata pajang, dan sirkulasi. Dilanjutkan dengan pengumpulan data primer yakni observasi secara langsung ke objek penelitian guna mengetahui secara langsung keseluruhan ruang pamer; penulis juga melakukan interview dengan beberapa pengunjung.

Untuk melihat desain interior museum yang berada di OHD Museum sebagai museum kontemporer dengan koleksi lukisan modern kontemporer yang terbaik dan telah menjadi ikon di Yogyakarta.

\section{HASIL DAN PEMBAHASAN}

Salah satu aspek ruang yang penting dalam menunjang berkembangnya seni dan terpeliharanya para seniman dalam melestarikan ide kreatif dan karya seni adalah museum. Dalam museum terdapat area ruang pamer yang dapat disebut juga galeri. Galeri seni memiliki tujuan dalam memelihara dan melestarikan seni dengan fokus terutama pada seniman dan para penikmat seni. Objek penelitian yang diambil adalah sebuah museum seni kontemporer yang berlokasi di Magelang. Museum seni ini adalah museum contemporary art; merupakan salah satu museum terbaik yang dimiliki Indonesia.

Permasalahan yang dilanda pada akhir abad ke-20 yakni masih terbatasnya sarana untuk mengembangkan ilmu seni rupa. Jumlah galeri di Indonesia masih sangat kurang, terutama yang dikelola secara profesional.

"Betapa sulitnya bagi seniman dalam mengembangkan profesinya jika tidak tersedia museum, pusat kesenian atau galeri seni rupa, tidak tersedia jurnal seni, dan tidak pernah ada kritik seni, semua fasilitas yang dapat membantu proses peningkatan profesi keseniman" (Yudiseputro, 1995, hlm 8-9). 
Untuk menjawab tantangan tersebut peranan pribadi seniman sangat menentukan untuk selalu berada dalam kondisi kreatif dan menggalang perintisan secara kesinambungan. Secara umum, fokus kegiatan ruang-ruang ini memang tidak terlepas dari misi para pendirinya untuk mendirikan semacam 'museum' untuk karya-karya mereka. Pendiri ruang-ruang itu menandai munculnya model patronase baru seni rupa yang digagas oleh seniman-seniman mapan (Ardjo, 2011, hlm. 490).

Pembangunan galeri seni rupa yang dibuat oleh pribadi atau swasta memiliki hubungan kerja sama dengan pihak-pihak tertentu, hal ini dikarenakan galeri seni rupa yang didirikan tentu harus memiliki sistem pengelolaan yang baik. Mengingat modal yang cukup besar dalam proses pendirian galeri seni rupa, seniman dan tim pengelola galeri harus cermat mengenai perkembangan seni di masyarakat. Dengan dasar sistem pengelolaan yang cermat dan peka terhadap perubahan dan permintaan pasar, maka akan banyak keuntungan yang diperoleh dari galeri seni rupa.

OHD Museum memiliki koleksi seniman dari mulai Nashar hingga abad modern, menjadi tempat untuk memancing kreativitas pengunjung, dan memberi inspirasi kepada masyarakat. Dengan membuat pameran dari koleksi seni modern dan kontemporer yang luar biasa dan terbaik. OHD Museum didedikasikan untuk mengomunikasikan antara masa lalu dan masa kini, baik yang sudah mapan, maupun yang masih eksperimental. Misi OHD Museum adalah untuk membantu pengunjung memahami dan menikmati seni zaman kini. Lokasi museum juga sangat strategis dan mudah dijangkau, di pusat perkotaan dan di jalan raya yang memang mudah ditemukan dan didukung dengan udara yang sangat sejuk.

Memamerkan karya masterpiece Indonesia dan selalu memiliki pameran yang terus berkembang dan kekinian, Museum OHD telah menjadi ikon Kota Magelang. Pengunjung dapat menikmati karya seni arsitektur, desain, karya lukisan, pahatan, fotografi, buku-buku ilustrasi, film, dan lukisan cetak di dalam Museum OHD. Sebelah kanan area lobi adalah ruang penitipan barang yang biasa ramai pada saat musim dingin di mana pengunjung museum akan menitipkan baju dingin mereka sebelum masuk ke ruang galeri.

OHD Museum masuk dalam kategori museum kontemporer yang bersifat campuran di mana terdapat koleksi yang permanen maupun yang mengikuti tren kekinian pada saat ini. Pengunjung dapat pula melihat masterpiece yang hanya dapat dinikmati di museum ini dan dijaga ketat oleh bagian keamanan.

\section{KESIMPULAN}

Studi ini bertujuan untuk mengevaluasi ruang seni yaitu museum kontemporer melalui sebuah observasi lapangan dan wawancara dengan pengunjung. Terlihat beberapa kekurangan maupun kelebihan di dalamnya. Secara spesifik, studi ini berhasil memperoleh deskripsi tentang pentingnya peningkatan pengelolaan museum untuk meningkatkan daya tarik bagi masyarakat dan juga ruang pamer pajang objek dalam museum kontemporer, yang berisi lukisan, instalasi, photography, karya seni, dan lain sebagainya. Selain itu, sirkulasi dan pencahayaan yang diterapkan dalam museum terkait dengan kualitas objek yang ingin dipamerkan cukup baik dan menunjang aktivitas 
Jurnal Tata Kelola Seni-Vol. 4 No. 2 Desember 2018

p-ISSN 2442-9589, e-ISSN 2614-7009

pengunjung museum. Kepuasan pengunjung terhadap museum dan antusiasme masyarakat terhadap museum kontemporer ini juga teridentifikasi melalui observasi penulis selama survei beberapa hari di dalam museum.

\section{KEPUSTAKAAN}

Appleton, I. 2008. Building for The Performing Arts: A Design and Development Guides. United Kingdom.

S. P. Swastika. 2012. "Galeri Seni Rupa Kontemporer di Yogyakarta”. hal 15.

Nakisbandiah. 2004. Kehidupanku bersama Barli. Bandung: Bale Seni Barli.

wisatabandung.com. 2015. Mengapresiasi karya seni lintas aliran di Museum Barli. [Online]. Tersedia: http://bandung.panduanwisata.id/ mengapresiasi-karya-senilintasaliran-di-museum-barli/ Diunduh: 03/12/2015 